\title{
The Global Battle for Sustainability Can Be Won or Lose In Cities
}

\author{
Ghurni Bhattacharya \\ Undergraduate student \\ Jadavpur University
}

\begin{abstract}
The paper titled 'The Global Battle For Sustainability Can Be Won or Lose in Cities' implies upon the fact that City with all its lifestyle and adopted practices impacts global sustainable development goals thereby plays a crucial part in maintaining balance ,Harmony and sustainability of the planet .
\end{abstract}

\section{INTRODUCTION}

The term 'Sustainable Development' involves human development, values and differences in cultures apart from the clutches of science and business development therefore "sustainable human development proposed by many organisations including gender equality, access to education, health, decision making stands in opposition to sustainable development .There are several definitions revolved such as "A community that believes today's growth must not be achieved at tomorrow's expense."-----Governor's Commission for a sustainable South Florida, initial report October 1995 though most widely known and considered definition of sustainable development was given by Brundtland Commision. Sustainability is nothing but capacity of systems that endures, remain diverse and productive over time whereas sustainable development revolves around social and economic developmental practices adopted by not altering ecological balance.

Dynamic adaptation of the human community consequences human settlements functioning in a web of social,economic and historical relations in a specific geographical territory representing totality of human communities, villages and towns which supports union of natural, social, material, spiritual, cultural as well as organisational factors .F Ratzal characterises city as professional activity, concentration of dwellings and number of inhabitants .Cities are epicentres of knowledge ,source of growth and innovation inspite of that provides room for social exclusion of specific group with lack of affordable residence , environmental issues, demographic and social inequalities being persisting factors proving social progress and economic growth depicting in Lisbon strategy a total failure thereby necessity for integrated strategies, coordinated actions by all individuals come in forefront throwing a beam of light to the future of cities in each layers of Government reflecting upon the broader picture of city as not just cluster and packing of houses but it's manifestations would spread worldwide being complex in nature . Major people resides in cities contributing to less green patches, strain on resources and cars on road, increase in temperature accompanied by walking biking gets more riskty ,housing becomes expensive and transit gets overcrowded, even livelihoods are wiped out forever due to natural calamity ,migration rate to urban areas is also high hence cities should be livable without destructing the globe thus concept of sustainable cities developed.

\section{BODY}

Cities being metropolitan areas occupying three percent land of the earth are powerhouses of economic growth yielding sixty percent of Gross Domestic Product accounting for seventy percent of global carbon emissions accompanied by sixty percent of resource use where inequalities go hand in hand coupled with the fact that one billion people live in slums and the number increased with rapid urban energy consumption and pollution level thus prone to climate change and natural disaster due to higher concentration of settlements thus urban resilience plays crucial role in avoiding losses along with pollution deteoriating individual's health affecting productivity of labor thereafter natural disaster along with economy disrupts individual's way of living hence the concept of sustainable cities emerged whose benefits is more than the cost of implementation of the sustainable practices .

The concept of Sustainable City is intertwined with providing basic amenities along with necessary infrastructure of Civic amenities in terms of health and medical care ,housing, education ,employment, transportation , governance and the infrastructure of sustainable city engages waste, water, sewage, food, parks, public spaces barring any discrimination where emphasis should be priorly given to those living in subhuman conditions in below poverty line charactising upon the fact of controlled population where adequate employment is accessible with adequate governance set up ensuring community participation ,Civic responsibilities ,planned housing colonies with proper infrastructure such as schools ,parks, drainage system, medicare etc ,facilitating well-knit transport system with the aim of reducing total vehicle kilometre driven in order to reduce pollution as well as effective environmental infrastructure reflecting crucial issues of waste polluting rivers, lakes and coastal zones and addressing untreated sewage ,development of health Care system highlighting upon the issues of nutrition, sanitation and family planning ,mechanization in policy initiative in terms of industrial dispersion for satellite townships accompanied by women empowerment in political, social, economic spheres of city and development of urban private sector with job opportunity is also one of the prime conditions where city yields basic amenities for reasonable standard of living where resources being regenerated and sustained and not depleted which consequences in advantageous situation as healthy cities contribute to build healthy nation though population growth, Inadequate economic growth and lack of funds ,increased shortage of residence ,strain on education and health care ,rapid increase in transportation network and non implementation of legislation stand as barrier in the development of sustainable cities though NGOs 
play a pivotal role depicting environmental issues for instance the Clean India initiative . FARN's research emphasized that water quality and noise quality can be benefitted from the establishment of sustainable city .Empowerment ,Security ,Opportunity ,Financing are considered to be some of the basic aspects of sustainable city .The rapid pace of urbanisation transforms socio economic fabric of Nation as well as cities play a crucial role to gain sustainable development being responsible for bulk production and consumption .education and focus of attention upon urban challenges and future opportunities, mobilization and Empowerment of all urban actors, addressal of challenges specific to urban poverty ,promotion of integrated innovative infrastructure design ,promotion of planning of land use and spatial concentration, ensure disaster risk reduction and climate change are some accomplishment of urban sustainable development goals which vividlly depicts the world's need for urban sustainable development goals .consequencing the facts that due to sustainable development lifespan of the people increased leading healthier lives ,life expectancy at birth for men,women combined increased eighty years ,Income having impact on life expectancy therefore rich and educated people live longer than poorer whereas genes considered to be not so important determining life expectancy whereas lifestyle does.

\section{CONCLUSION}

It is clearly evident throughout this paper that establishment of sustainable cities is essential as healthy cities would contribute to build healthy nation associating far reaching global impacts hence adoption of ways such as empowering cities including delegation of more financial power to cities, need for national level support ,importance of integrating new migrants into urban fabric, preparation for future tasks in order to make city life more livable and sustainable thereby the title of the paper is justified following the argument of the paper .

\section{REFERENCES}

[1] http://archive.rec.org/REC/Programs/SustainableCities/AdvantagesArgentina.html

[2] https://www.intechopen.com/books/sustainable-cities-authenticity-ambition-and-dream/introductory-chapter-overviewof-sustainable-cities-theory-and-practices

[3] https://www.devalt.org/newsletter/jul00/lead.htm

[4] https://www.nrdc.org/experts/shelley-poticha/future-green-why-we-need-sustainable-cities

[5] https://www.weforum.org/agenda/2015/02/how-sustainable-cities-can-improve-lives/

[6] https://www.afd.fr/en/actualites/these-12-indian-cities-are-future-sustainable-urban-development

[7] https://en.m.wikipedia.org/wiki/Sustainable_city

[8] https://www.smartcitiesdive.com/ex/sustainablecitiescollective/21-features-future-sustainable-city/285946/

[9] https://www.bbc.co.uk/bitesize/guides/zqvxdmn/revision/2

[10] https://oxfamliving.oxfam.org.au/2017/08/21/5-essential-features-of-sustainable-cities-and-eco-cities/

[11] https://www.connect4climate.org/infographics/how-can-cities-become-more-sustainable-klimalog-bmzl

[12] https://alum.mit.edu/slice/how-can-cities-become-more-livable

[13] https://www.thenatureofcities.com/2013/05/08/the-cities-we-want-resilient-sustainable-and-livable/

[14] https://www.weforum.org/agenda/2015/09/10-key-steps-to-make-our-cities-liveable-by-2030/

[15] https://www.smartcitiesdive.com/ex/sustainablecitiescollective/21-features-future-sustainable-city/285946/

[16] https://blogs.scientificamerican.com/observations/3-ways-cities-can-become-more-sustainable/

[17] https://ehs.unu.edu/news/news/five-ways-to-make-cities-more-sustainable-and-resilient.html

[18] https://ensia.com/notable/sustainable-cities/

[19] https://theconversation.com/amp/our-cities-need-to-go-on-a-resource-diet-68984

[20] https://link.springer.com/referenceworkentry/10.1007\%2F978-1-4419-0851-3 441 